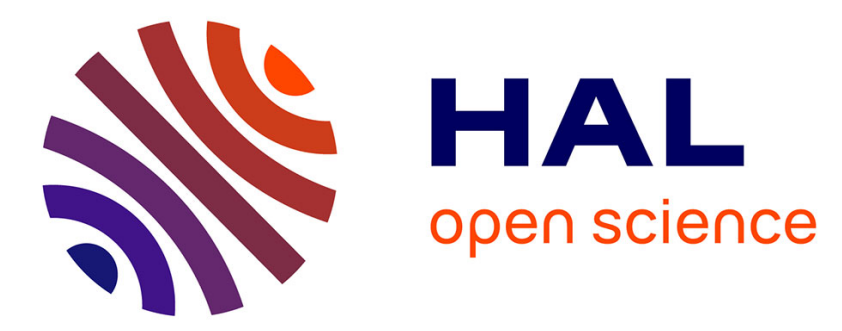

\title{
Fish community structure in relation to environmental variation in coastal volcanic habitats
}

Mathieu Pinault, Claire Bissery, Gilles Gassiole, Hélène Magalon, Jean-Pascal Quod, René Galzin

\section{- To cite this version:}

Mathieu Pinault, Claire Bissery, Gilles Gassiole, Hélène Magalon, Jean-Pascal Quod, et al.. Fish community structure in relation to environmental variation in coastal volcanic habitats. Journal of Experimental Marine Biology and Ecology, 2014, 460, 10.1016/j.jembe.2014.06.005 . hal-01253768

\section{HAL Id: hal-01253768 https://hal.science/hal-01253768}

Submitted on 4 May 2016

HAL is a multi-disciplinary open access archive for the deposit and dissemination of scientific research documents, whether they are published or not. The documents may come from teaching and research institutions in France or abroad, or from public or private research centers.
L'archive ouverte pluridisciplinaire HAL, est destinée au dépôt et à la diffusion de documents scientifiques de niveau recherche, publiés ou non, émanant des établissements d'enseignement et de recherche français ou étrangers, des laboratoires publics ou privés. 


\title{
Fish community structure in relation to environmental variation in coastal volcanic habitats
}

\author{
Mathieu Pinault a,b,*, Claire Bissery ${ }^{\text {c }}$, Gilles Gassiole ${ }^{\mathrm{d}}$, Hélène Magalon b,f , Jean-Pascal Quod ${ }^{\mathrm{e}}$, René Galzin ${ }^{\mathrm{a}, \mathrm{f}}$ \\ a USR 3278 CNRS-EPHE, CRIOBE and CBETM University of Perpignan, 66860 Perpignan, France \\ ${ }^{\mathrm{b}}$ Laboratory of Marine Ecology (ECOMAR), University of Reunion Island, FRE3560 INEE-CNRS, 15 Avenue René Cassin, BP 7151, 97715 Saint-Denis, Reunion \\ c 7 rue Pascal, 29200 Brest, France \\ d Asconit Consultants, 16, rue Albert Lougnon, 97490 Sainte-Clotilde, Reunion \\ e Agency for Marine Research and Exploitation (ARVAM), 2, Rue Maxime Rivière, 97490 Sainte-Clotilde, Reunion \\ ${ }^{\mathrm{f}}$ Laboratory of Excellence 'CORAIL', BP 1013 Moorea, 98729, French Polynesia
}

\begin{abstract}
A B S T R A C T
This study constitutes one of the few works conducted on the colonization of recent lava flows by fish communities in coral reef environment. It attempted to describe the mechanisms of colonization and environmental variables influencing the structure of communities on the lava flows of the Piton de la Fournaise volcano at Reunion Island. It also proposed some hypotheses on the mechanisms of selection and speciation of endemic species of the southwestern Indian Ocean region, particularly diversified on the most recent lava flows of the Piton de la Fournaise, and provided a model of distribution of environmental and fish assemblage variables in four homogeneous patterns of colonization (landscapes) retained within the study area. The results showed fish community structure strongly related to measured environmental variables, of which depth, width of the island shelf, age of the lava flow and distance to the most recent lava flow were the most influential. It also appeared that the maximum endemic species richness was measured on the shallower stations, with narrow insular shelf, located on recent lava flows, near the lava flow from the eruption of 2007 (latest volcanic event). These characteristics define a harsh environment, to which endemic species seem well-adapted due in particular to their strong demographic and dietary flexibility. Finally, the patterns of colonization were characterized by significantly different environmental variables. The four homogeneous areas, defined by two geomorphological features, basalt blocks and drop-offs, nested within two locations, inside and outside the volcanic enclosure (current caldera), hosted fish communities whose dominant diets mainly depend on the nature, the abundance and the accessibility of available food resources. Overall, the study highlights that during early stages of ecological succession, site selection by fish communities is highly dependent on environmental constraints, especially of volcanic origin, but the physical habitat selection (geomorphology, substrate rugosity, percentage of soft substrate) seems to have little importance, while at least on the trophic structure and the distribution of endemic species.
\end{abstract}

\section{Introduction}

The ecological requirements of tropical marine fishes have been extensively studied for 50 years including their community structure and interactions of communities with environmental variables such as substrate rugosity (e.g. Chabanet et al., 1997; Gratwicke and Speight, 2005), benthic organism cover (e.g. Bell and Galzin, 1984; Chabanet and Faure, 1994), depth (e.g. Booth and Wellington, 1998; Friedlander and Parrish, 1998), proportion of soft substrate (e.g. Khalaf and Kochzius, 2002; Travers et al., 2010), and intensity of a volcanic disturbance (e.g.

\footnotetext{
* Corresponding author at: Laboratory of Marine Ecology (ECOMAR), University of Reunion Island, FRE3560 INEE-CNRS, 15 Avenue René Cassin, BP 7151, 97715 SaintDenis, Reunion. Tel.: + 262693001406.

E-mail address: math.pinault@gmail.com (M. Pinault).
}

Godwin and Kosaki, 1989; Pinault et al., 2013b). However, no model attempting to explain fish community structure in relation to environmental variables has been constructed for an active volcanic area.

Otherwise, the southwestern Indian Ocean (SWIO) region, comprising a main landmass, Madagascar, and several island archipelagos such as Comoros, Mascarenes and Seychelles, each with different origins and ages, hosts a high proportion of endemics and is highly threatened by human activities, hence its classification as a marine biodiversity hotspot (Bellard et al., 2013; Roberts et al., 2002). This region constitutes a natural laboratory for studying diversification processes in coastal marine taxa, whose rocky shore species have been yet little studied (Postaire et al., 2014).

This lack of information can be attributed to the traditional focus on coral reefs, often considered to host the highest biodiversity in the tropics (Sale, 1991), and to difficulties in standardization of sampling 
methods to the geomorphological and ecological specificities of rocky shore habitats, including volcanic areas (Pinault et al., 2013b).

Reunion Island is one of the few places where volcanic activity is frequent, with 27 eruptions occurring between 1998 and 2007 and a mean frequency of an eruptive phase every 9 months over the past century (Tanguy et al., 2011). It is also one of the few places where lava frequently flows into the ocean (Michon and Saint-Ange, 2008). Community development on lava flows is of considerable interest to the natural history of Reunion Island and the Mascarene Archipelago. Although terrestrial succession on lava has been well studied at Reunion (Strasberg, 1995), the development of fish assemblages has been monitored only by Pinault et al. (2013b, in press) on the submerged flows of the Piton de la Fournaise.

The aims of this study were to (1) estimate the relative influence of environmental variables on the fish community structure settled on recently formed habitats regularly subjected to acute disturbances, (2) explain the distribution of endemic species in the SWIO rocky shore habitats exploring their adaptation to environmental variability, and (3) propose a fish colonization pattern on the surveyed volcanic area according to the main underwater landscapes and their specific environmental variables.

\section{Material and methods}

\subsection{Study site}

Reunion is an island of the Mascarene Archipelago, with Mauritius and Rodrigues Islands, $690 \mathrm{~km}$ east of Madagascar $\left(21.06^{\circ} \mathrm{N}, 55.33^{\circ} \mathrm{E}\right)$ (Fig. 1). Of recent volcanic origin (between 1.5 and $8 \mathrm{Ma}$ ), the three islands have undergone alterations following successive eruptive phases. Reunion Island consists of two volcanoes, the Piton des Neiges and the Piton de la Fournaise: The former has been extinct for $\mathrm{c}$. 70,000 years, while the latter is still active with effusive eruptions (Chevallier and Vatin-Perignon, 1982).

The coastline of Reunion is characterized by a narrow insular shelf and steep slopes. The west-southwest coast is urbanized, with fringing coral reefs extending for about $25 \mathrm{~km}$ ( $12 \%$ of the total coastline) (Pinault et al., 2013a). The north coast, relatively shielded from the effects of trade winds, is also densely populated. It receives 9 of the 13 perennial river mouths and is characterized by turbid waters and a high proportion of soft substrate. The southeast region of the island, deeply marked by recent and ongoing volcanic activity of the Piton de la Fournaise, is sparsely inhabited. Most of the historic eruptions of the Piton de la Fournaise $(2002,2004,2005,2007)$ have been from vents located inside the walls of the current caldera or volcanic enclosure (VE), at various elevations along the rift zone, but three of the most recent four large-volume deep-seated eruptions $(1977,1986,1998)$ have had at least one vent located outside of the caldera rim, along an extension of the intracaldera rift zone (Vigouroux et al., 2009). This volcanic area is exposed to trade winds and is characterized by regular swells, sometimes strong, particularly during the austral winter (Bollard et al., 2013), and by widespread runoff and percolation generated by heavy rainfall.

The shoreline of the VE, which forms the southern area of the study site, consists of sea cliffs 3 to $8 \mathrm{~m}$ high that continue vertically underwater to depths of 3 to $5 \mathrm{~m}$. The deeper areas of the flows consist largely of unconsolidated lava boulder, loose rocks, and rubble, with the bottom sloping into deep water at an angle of c. $30^{\circ}$. The area immediately to the north of the VE, which forms the central area of the study site, is on a prehistoric flow of undetermined age. First evidence of an eruption of the Piton de la Fournaise dates from 1640, but many flows occurred before that date (McDougall, 1971). The northern area of the study site consists of the 1977 flow, which entered the sea outside the VE, creating a shoreline c. $750 \mathrm{~m}$ wide with sea cliffs 3 to $5 \mathrm{~m}$ high and narrow black sand beaches. The substratum immediately offshore, deposited by prehistoric and the 1977 flows, consists of 1 to $3 \mathrm{~m}$ diameter angular boulders and slopes steeply to a depth of $8 \mathrm{~m}$. Between 8 and $20 \mathrm{~m}$, the bottom slopes downward more gradually; beyond the $20 \mathrm{~m}$ contour the bottom once again drops away at a steep angle. The substratum between 8 and $20 \mathrm{~m}$ consists of compact wave-smoothed lava with high algal cover. Pocillopora verrucosa (Ellis and Solander, 1786), Pocillopora eydouxi Milne-Edwards and Haime, 1860, Pocillopora damicornis (Linnaeus, 1758), and Pocillopora meandrina Dana, 1846 are the most abundant corals, but cover is sparse and tends to be concentrated in the northern reaches of the area. Well-developed coral communities were found between 10 and 25 m north of the study site on the 1977 flow and at the Caesari Rock and Waterfalls Bay areas (Fig. 1, transects

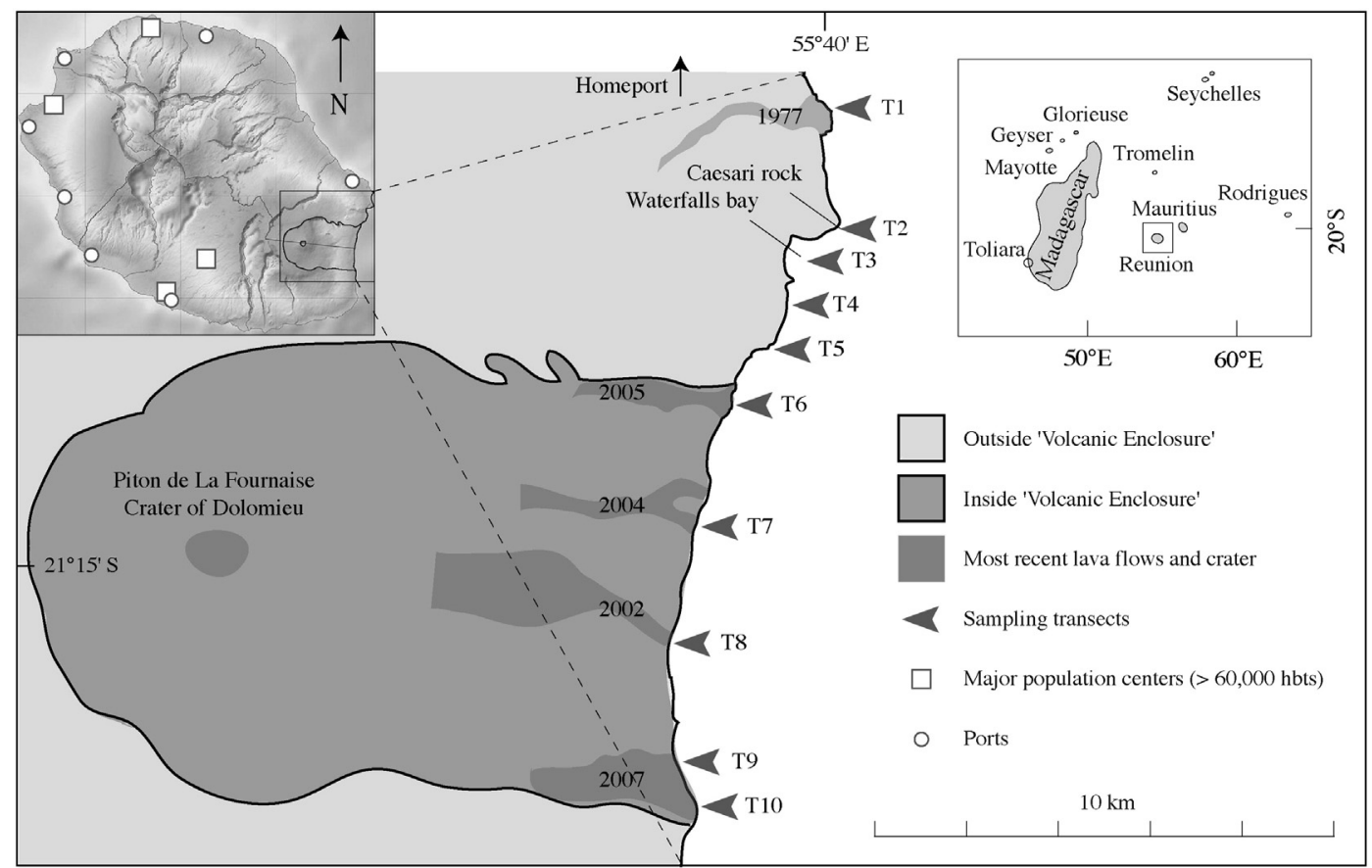

Fig. 1. Location of the ten sampling transects along the slopes of the Piton de la Fournaise - Reunion Island, southwestern Indian Ocean. 
1-3). Although the health status of the coral communities was good in the two northernmost areas (transects $1-2$ ), the corals were partially dead or necrotic in Waterfalls Bay (transect 3).

\subsection{Sampling method}

Fieldwork took place over an eight-day period in late November 2011 (austral summer). Surveys were taken at thirty-eight stations at depths from 5 to $30 \mathrm{~m}$ within 10 linear transects perpendicular to the shore (Fig. 1). Each transect contained four sampling stations (5-10, 11-15, 16-20, and 21-30 m) except for T2 and T10, which contained three stations (10-15, 16-20, and 21-30 $\mathrm{m}$ ) because high surge conditions and limited visibility due to a "mist" of fine air bubbles made it impossible to survey the shallow sub-tidal communities on the final survey day. The transects were located along the shore in two sectors inside and outside the VE, on flows of different ages. All surveys took place between 0900 and $1600 \mathrm{~h}$.

The deepest end of each transect ( $30 \mathrm{~m}$ ) was located by dropping a weighted float overboard after recording the station position with a Garmin eTrex GPS receiver (www.garmin.com). Two trained divers equipped with slates, pencils and data sheets moved randomly over an estimated area of $300 \mathrm{~m}^{2}$ at depths of 21 to $30 \mathrm{~m}$, recording each observed species using underwater visual census (UVC) techniques, and estimating hard substrate rugosity, soft substrate percentage, coral and algal cover using a habitat assessment score following the methods of Pinault et al. (2013a) (station 1). When 15 min had elapsed, the divers moved toward shore and repeated the protocol at 16 to $20 \mathrm{~m}$ depth (station 2), then 11 to $15 \mathrm{~m}$ (station 3 ), and finally 5 to $10 \mathrm{~m}$ (station 4 ). The UVC is a non-destructive, capture-independent method, superior to collection techniques, especially in sensitive areas. Underwater visual censuses require little post-processing, whereas collections take many hours to complete. The method does, however, tend to underestimate the numbers of small, nocturnal, and cryptic fish (Ackerman et al., 2004; Fowler, 1987; Harmelin-Vivien et al., 1985; Pinault, 2013; Willis, 2001). In order to minimize this bias, a stratified sampling method consisting of dividing the population into homogeneous sub-groups can be implemented (Labrosse et al., 2002). In this study, two strata were created, based mainly on the behavior of the observed fish species: (1) demersal and pelagic species such as Labridae, Pomacentridae, and Carangidae and (2) mimetic, burrowing and cave species such as Gobiidae, Scorpaenidae, and Muraenidae. Each diver surveyed one stratum in an identical manner (same sampling time, way and surface).

\subsection{Fish assemblage variables}

Recorded species were assigned to eight groups according to diet, based on extensive published data (Froese and Pauly, 2012; Hiatt and Strasburg, 1960; Hobson, 1974; Myers, 1999): (1) herbivores, grazing on microalgae or macrophytes; (2) omnivores, feeding opportunistically on available food, including organic debris; (3) browsers of sessile invertebrates, feeding mainly on coral polyps, but also on other fixed organisms; (4) diurnal and (5) nocturnal carnivores, consuming benthic invertebrates; (6) piscivores, preying on other fish; and (7) diurnal and (8) nocturnal planktivores, capturing plankton, mainly animal. Only the primary trophic assignment of each species was included in the analyses. When authorities presented conflicting information for a given species, the most common trophic assignment was selected.

Ecological traits were defined based on species biological and behavioral characteristics such as asymptotic length $\left(\mathrm{L}_{\infty}\right)$, minimum and maximum depths, migratory behavior and fecundity. The asymptotic length was provided by the von Bertalanffy growth equation parameters (Bertalanffy, 1938), available in Froese and Pauly (2012). The minimum and maximum depths were found in Lieske and Myers (1994). The migratory behavior was determined using McPherson and Jetz (2007). Species closely associated with their habitat and generally characterized by a narrow species range-size were classified as sedentary. Conversely, seasonal visitors and species exhibiting local movements within the study area were treated as nomadic. The species fecundity was deduced from Froese and Pauly (2012). Species with minimum population doubling time less than 15 months were classified as highly fecund. Others were indistinctly considered as moderately or least fecund.

Endemic species of the SWIO region (SWIO species), in the sense of Pinault et al. (2013b), were considered as the most representative of the patrimonial value of the stations. They were treated separately from the non-endemic species (non-SWIO species) in proper analyses. A biogeographic pattern was provided per species by the online system AquaMaps (Kaschner et al., 2010), a tool using a niche modeling approach (Hutchinson, 1957) to generate predicted distributions of marine species based on available distribution data or described ecological tolerances. In essence, provided that a minimum acceptable level of information is available, the tool will generate a predicted distribution for any species, calculated by the probability of occurrence in the entire ocean. Predicted distributions, based on ecological tolerances, often present ranges that exceed the actual known distribution of species, because the geographic distributions of suitable ecological variables usually extend over a much greater area than the known ranges of species (Rees, 2008). This theoretical approach was essential in order to assess the distribution of rare species and especially species not previously recorded from Reunion Island. This method, however, ignores the evolutionary constraints, providing ranges that would be possible if dispersal was not limited by geological history, which is particularly complex in volcanic oceanic islands (Postaire et al., 2014). It is therefore possible that some model-based distribution patterns are broader than what exist in reality. Some species identified as restricted to the SWIO area could be thus restricted to a smaller range, as the Mascarene Islands.

\subsection{Additional environmental variables}

The width of the island shelf in meters and the distance from the most recent lava flow (2007) in kilometers were estimated by geographic information system (GIS), using MapInfo professional software (www.mapinfo.com). For each station, the width of the insular shelf was measured transversely to the shore from the high tide line to the $-100 \mathrm{~m}$ isobath using the bathymetric map of the naval hydrographic and oceanographic service (SHOM).

The age of the lava flows was calculated in years before the survey period. The flow from the 2007 eruption was, for example, estimated at 4 years. The four transects with undetermined ages (Fig. 1, T2-5) were considered to have more than 371 years, the first evidence of an eruption of the Piton de la Fournaise dating back to 1640 (McDougall, 1971).

\subsection{Underwater landscape features}

Despite the diversity of underwater landscapes observed during survey, only two geomorphologies: basalt blocks and drop-offs and two locations: outside (Fig. 1, T1-5) and inside VE (T6-10) were retained. The nested design of these two factors led to the creation of four main underwater landscapes: basalt blocks outside VE, basalt blocks inside VE, drop offs outside VE, and drop offs inside VE.

Basalt blocks consist of large lava boulders and loose rocks caused by the erosion of the sea cliffs that constitutes the coastline of the study site. These blocks accumulate over wave-smoothed compact lava from successive eruptive phases, sloping into deeper water at a slight angle. Drop-offs consist of compact lava cliffs, sloping steeply on sedimentary patches including a mixture of olivine sand and centimetric scoria gravel. The basalt cliffs frequently have columnar appearance typically known as basalt organ pipes, because of their regular hexagonal shape.

The area outside VE consists of wave-smoothed volcanic rocks, generally more colonized by sessile marine fauna and flora than the area inside VE. Littoral benthic ecosystems are inhabited by a multitude 
of herbivorous and lithophagous organisms that strongly influence the underwater landscape mosaic by their selective grazing and bioerosive action. In contrast, the area inside VE, including the most recent lava flows of the Piton de la Fournaise, exhibits mineral landscapes, which consist of unconsolidated lava boulders, scoria gravel and rubble, with very steep slopes. The background colors are dark in crystal clear seawater.

\subsection{Data analysis}

To assess spatial variation, environmental variable values were compared among underwater landscapes using a two-stage nested design in analysis of variance (nested ANOVA, geomorphology nested within location) (Montgomery, 1976). The normality of the statistical distribution of the environmental variables was assessed by a Shapiro-Wilk test (Shapiro and Wilk, 1965). Bartlett's test for homogeneity of variances (Snedecor and Cochran, 1989) was used to verify whether values measured in different geomorphologies and locations had equal variances. When necessary, the one-parameter Box-Cox transformation (Box and Cox, 1964) was implemented to reduce anomalies such as non-additivity, non-normality, and heteroscedasticity (Sakia, 1992).

The relationships between fish assemblage structure (species occurrences) and environmental variables were elucidated using a canonical correspondence analysis (CCA) (ter Braak, 1986). It is a fact that rare species are often positioned as outliers in correspondence analysis ordinations (Greenacre, 2013). Furthermore, statistical estimation problems are posed by multicollinearity (ter Braak, 1986). In this sense, species occurring at less than 10 stations and significantly correlated environmental variables (correlation test - Pearson, 1957) were omitted from analysis prior to conducting CCA. A Monte-Carlo randomization test (1000 permutations) (McCune and Grace, 2002) was used to assess the probability of the observed pattern being due to chance.

Multiple regression analyses (Efroymson, 1960) were then implemented to test the relationships between fish assemblage variables (diets and biogeographic patterns) and environmental variables. One analysis was conducted per fish assemblage variable, integrating environmental variables as predictors. For the same reasons as for the CCA, significantly correlated environmental variables were excluded from data prior to conducting multiple regression analyses.

Finally, it might be argued that different landscapes should exhibit inherently different fish assemblage variable values, and that any observed among-site differences are due to geomorphology or location rather than rugosity, depth, or other quantitative environmental variables. This hypothesis was tested only for the SWIO species richness, which is considered as the most representative fish assemblage variable of the patrimonial value of the stations, by treating geomorphology and location as fixed factors and some environmental variables (significant predictors of the multiple regression analysis) as covariates in a twoway analysis of covariance (ANCOVA) (Jöreskog, 1970).

Statistical significance testing was set at 0.05 . All statistical analyses were performed with R (R Development Core Team; www.r-project. org) using packages vegan (Oksanen et al., 2008) and MASS (Venables and Ripley, 2002).

\section{Results}

\subsection{Spatial variation}

The basalt blocks were characterized by significantly shallower depths (nested ANOVA, $\mathrm{p}<0.001$ ), higher percentages of coral cover $(\mathrm{p}=0.016)$, and lower proportions of soft substrate $(\mathrm{p}=0.028)$ than the drop-offs (Table 1). The area outside VE was distinguished by significantly longer distances to the most recent lava flow $(p<0.001)$, older ages $(\mathrm{p}<0.001)$, higher percentages of coral cover $(\mathrm{p}=0.001)$, and a wider insular shelf $(\mathrm{p}<0.001)$ than the area inside VE. Only the percentages of coral cover showed significantly different values between geomorphologies and locations. Thus, corals seemed to grow well on basalt blocks outside VE. In contrast, algal cover and rugosity showed no significant differences among underwater landscapes $(\mathrm{p}>0.05)$.

\subsection{CCA analysis}

Width of the insular shelf, age of the lava flow and distance to the most recent lava flow were highly correlated (Pearson test, $\mathrm{p}<0.001$ ) signifying that recent lava flows tend to increase the slope between the shoreline and the depth at $100 \mathrm{~m}$. Similarly, coral cover was positively correlated with distance to the most recent lava flow $(\mathrm{p}<0.001)$ and negatively correlated with soft substrate $(\mathrm{p}<0.001)$. The negative influence of the most recent lava flow on coral communities may be the result of the stress suffered by the entire coastal ecosystem within the study area at the latest eruption of the Piton de la Fournaise in 2007. Finally, rugosity was negatively correlated with algal cover ( $\mathrm{p}<0.001)$; thus, algal communities seem to develop preferentially on wave-smoothed volcanic rocks. Since these relationships caused multicollinearity problems, age of the lava flow, distance to the most recent lava flow, and algal and coral covers were excluded from further analyses.

The CCA revealed that spatial (Fig. 2A) and fish assemblage (Fig. 2B) patterns are strongly related to the underwater landscapes of the surveyed area.

The first axis, which is mainly a linear combination of the percentages of soft substrate and the width of the insular shelf, separates stations outside VE (right of the axis) and those located inside VE (left of the axis). Fish species that occurred mainly outside VE were characterized by higher proportions of browsers of sessile invertebrates [14\% vs. $9 \%$ inside VE, Chaetodon guttatissimus Bennett, 1833, Forcipiger flavissimus Jordan and McGregor, 1898, Pomacanthus imperator (Bloch, 1787)], while those occurring mainly inside VE presented greater percentages of omnivores [ $29 \%$ vs. $19 \%$ outside VE, Acanthurus dussumieri Valenciennes, 1835, Acanthurus mata (Cuvier, 1829), Chaetodon kleinii Bloch, 1790, Pomachromis richardsoni (Snyder, 1909), Pseudanthias squamipinnis (Peters, 1855)] and SWIO species [19\% vs. 9\% outside VE, Bodianus macrourus (Lacepède, 1801), Cirrhitichthys guichenoti (Sauvage, 1880),

Table 1

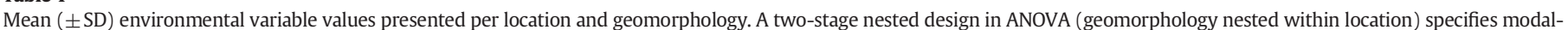
ities having significantly higher (a) and lower (b) values.

\begin{tabular}{|c|c|c|c|c|}
\hline \multirow[t]{2}{*}{ Environmental variables (units) } & \multicolumn{2}{|l|}{ Location } & \multicolumn{2}{|l|}{ Geomorphology } \\
\hline & Outside volcanic enclosure $\mathrm{n}=19$ & Inside volcanic enclosure $n=19$ & Basalt blocks $n=24$ & Drop-offs $n=14$ \\
\hline Dist. to the latest lava flow (km) & $9.7 \pm 0.8^{\mathrm{a}}$ & $2.3 \pm 2.9^{b}$ & $7.0 \pm 4.0$ & $5.1 \pm 4.5$ \\
\hline Age of lava flows (years) & $323 \pm 121^{\mathrm{a}}$ & $7 \pm 2^{\mathrm{b}}$ & $213 \pm 183$ & $121 \pm 173$ \\
\hline Depth $(\mathrm{m})$ & $16.9 \pm 5.3$ & $15.0 \pm 7.5$ & $13.5 \pm 6.0^{\mathrm{b}}$ & $21.0 \pm 3.4^{\mathrm{a}}$ \\
\hline Coral cover (\%) & $19.8 \pm 20.5^{\mathrm{a}}$ & $3.9 \pm 2.9^{b}$ & $17.1 \pm 19.5^{\mathrm{a}}$ & $4.4 \pm 6.2^{\mathrm{b}}$ \\
\hline Algal cover (\%) & $52.5 \pm 13.9$ & $45.2 \pm 20.7$ & $52.5 \pm 14.7$ & $42.8 \pm 20.9$ \\
\hline Soft substrate (\%) & $11.6 \pm 10.6$ & $18.1 \pm 17.8$ & $9.7 \pm 7.2^{\mathrm{b}}$ & $23.7 \pm 20.0^{\mathrm{a}}$ \\
\hline Rugosity ( $1-5$ scale) & $3.1 \pm 1.0$ & $3.5 \pm 0.8$ & $3.3 \pm 1.0$ & $3.2 \pm 0.9$ \\
\hline Width of insular shelf (m) & $592 \pm 213^{a}$ & $265 \pm 25^{\mathrm{b}}$ & $445 \pm 219$ & $446 \pm 254$ \\
\hline
\end{tabular}



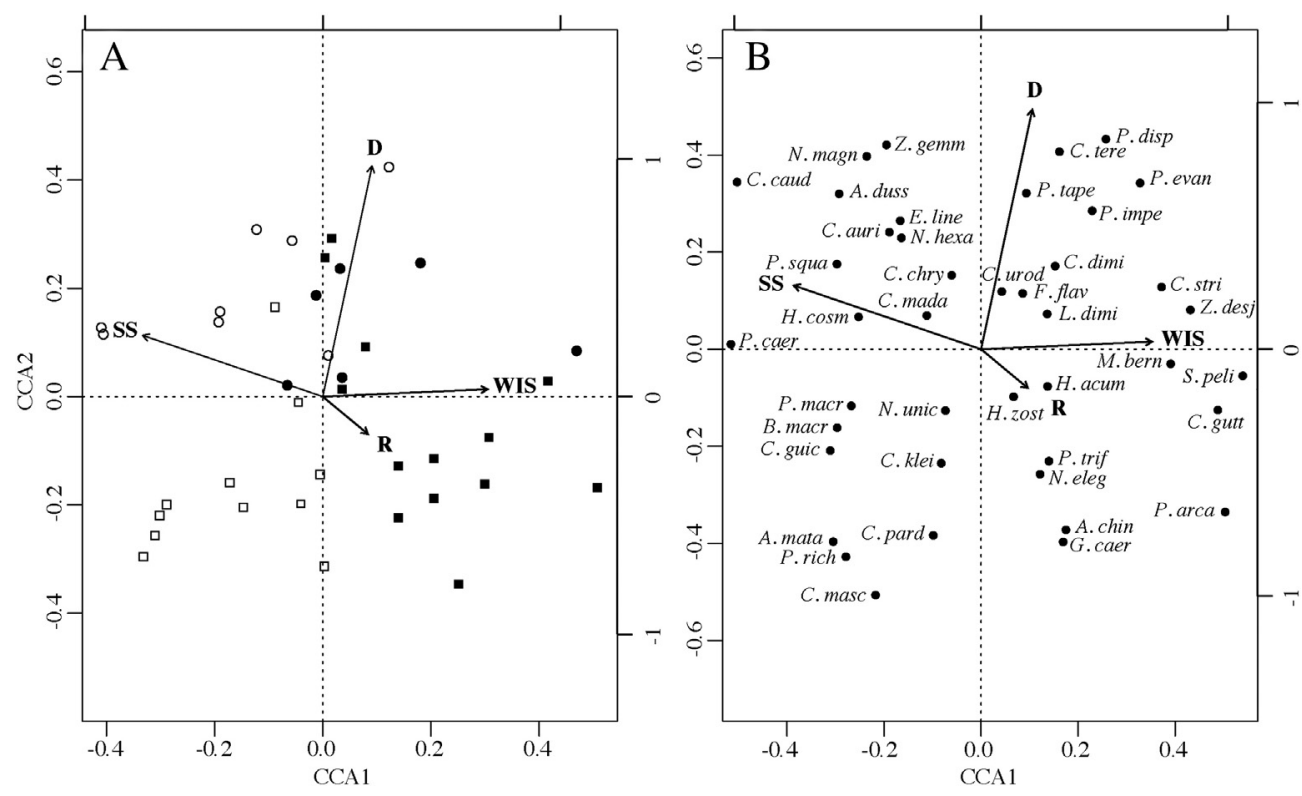

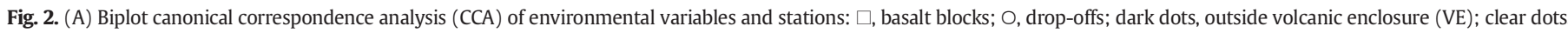

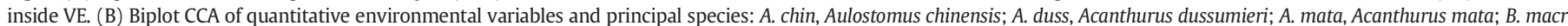

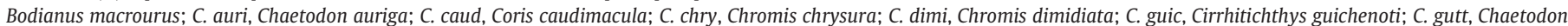

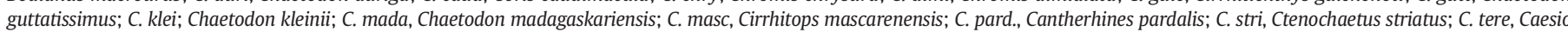

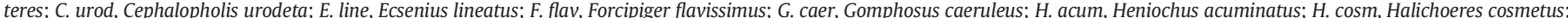

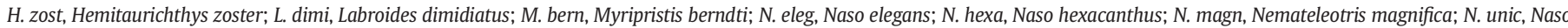

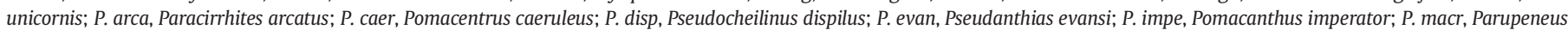

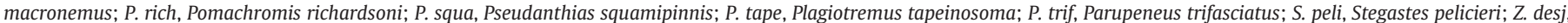

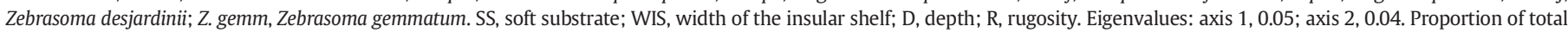

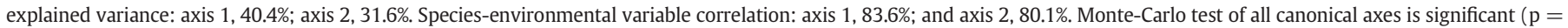
0.001), 1000 permutations.

Halichoeres cosmetus Randall and Smith, 1982, Zebrasoma gemmatum (Valenciennes, 1835)].

The second axis, mainly related to depth, distinguishes drop offs (top of the axis) and basalt blocks (bottom of the axis). Fish species that occurred mainly on basalt blocks presented a higher percentage of nocturnal carnivores [ $16 \%$ vs. $0 \%$ on drop offs, C. guichenoti (Sauvage, 1880 ), Cirrhitops mascarenensis Randall and Schultz, 2008, Paracirrhites arcatus (Cuvier, 1829)], while those occurring mainly on drop offs presented a greater percentage of diurnal and nocturnal planktivores [22\% vs. 5\% on basalt blocks, Pseudanthias evansi (Smith, 1954), Chromis chrysura (Bliss, 1883), Caesio teres Seale, 1906, Nemateleotris magnifica Fowler, 1938, Naso hexacanthus (Bleeker, 1855)].

\subsection{Linear regressions}

Only two fish assemblage variables were significantly related to the combination of the four independent environmental variables: the percentages of browsers of sessile invertebrates and the SWIO species richness, which $38 \%$ and $35 \%$ of the variance were predicted by the models respectively (Table 2). However, if the individual contributions of predictors on the fish assemblage variables are explored, several relationships appear to be significant. Thus, the width of the insular shelf contributed significantly to the percentages of browsers of sessile invertebrates (positive relations), omnivores and diurnal planktivores and to the SWIO species richness (negative relations). In the same way, the depth was significantly related to the percentages of diurnal and nocturnal planktivores (positive relations), nocturnal carnivores and to the SWIO species richness (negative relations). Finally, the rugosity was significantly related to the percentages of piscivores (positive relation). It can be noticed that the proportion of soft substrate was not significantly related to any fish assemblage variable.

The two significant predictors of the SWIO species richness were incorporated as environmental covariates into an ANCOVA (Table 3) to assess the specific effect of geomorphologies and locations (fixed factors) on the SWIO species richness (dependent variable) regardless of the effect of depth and width of the insular shelf. The results of the model confirmed the significant effect of the two covariates on the SWIO species richness but no significant effect of the two fixed landscape factors or

Table 2

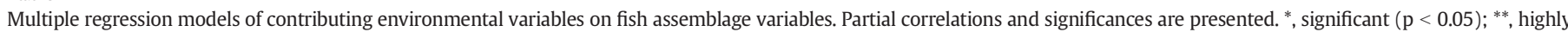
significant $(\mathrm{p}<0.01)$

\begin{tabular}{|c|c|c|c|c|c|}
\hline Fish assemblage variables & Depth & Soft substrate & Rugosity & Width of the insular shelf & Multiple $\mathrm{R}^{2}$ \\
\hline Herbivores & 0.02 & 0.29 & 0.28 & 0.20 & 0.18 \\
\hline Omnivores & 0.03 & -0.29 & -0.07 & $-0.34^{*}$ & 0.17 \\
\hline Browsers of sessile inverteb. & -0.13 & 0.08 & $0.34^{*}$ & $0.60^{* *}$ & $0.38^{* *}$ \\
\hline Diurnal carnivores & -0.28 & 0.26 & -0.16 & -0.12 & 0.22 \\
\hline Nocturnal carnivores & $-0.37^{*}$ & 0.05 & 0.23 & 0.04 & 0.17 \\
\hline Piscivores & 0.13 & 0.32 & $0.34^{*}$ & -0.21 & 0.23 \\
\hline Diurnal planktivores & $0.36^{*}$ & 0.05 & -0.16 & $-0.37^{*}$ & 0.23 \\
\hline Nocturnal planktivores & $0.41^{*}$ & -0.07 & -0.09 & -0.01 & 0.17 \\
\hline SWIO species richness & $-0.42^{*}$ & -0.02 & -0.13 & $-0.42^{*}$ & $0.35^{* *}$ \\
\hline Non-SWIO species richness & -0.10 & 0.13 & 0.32 & 0.19 & 0.11 \\
\hline Total species richness & -0.19 & 0.13 & 0.26 & 0.07 & 0.09 \\
\hline
\end{tabular}


Table 3

Analysis of covariance table showing results of the cumulative effect of width of the insular shelf and depth (covariates) on the southwestern Indian Ocean species richness (dependent data) measured in the two geomorphologies and the two locations (fixed factors). Df, degrees of freedom; SS, sum of squares; MS, mean square; F, F-statistics; p, p-value *, significant $(\mathrm{p}<0.05)$.

\begin{tabular}{lrrrrl}
\hline Source & df & \multicolumn{1}{l}{ SS } & \multicolumn{1}{c}{ MS } & \multicolumn{1}{l}{ F } & p \\
\hline Width of the insular shelf $($ WIS $)$ & 1 & 40.94 & 40.94 & 7.35 & $0.01^{*}$ \\
Depth & 1 & 33.01 & 33.01 & 5.93 & $0.02^{*}$ \\
Geomorphology & 1 & 0.42 & 0.42 & 0.08 & 0.79 \\
Location & 1 & 0.55 & 0.55 & 0.10 & 0.76 \\
WIS $\times$ depth & 1 & 0.59 & 0.59 & 0.11 & 0.75 \\
WIS $\times$ geomorphology & 1 & 0.00 & 0.00 & 0.00 & 0.99 \\
Depth $\times$ geomorphology & 1 & 2.53 & 2.53 & 0.45 & 0.51 \\
WIS $\times$ location & 1 & 0.14 & 0.14 & 0.03 & 0.87 \\
Depth $\times$ location & 1 & 1.39 & 1.39 & 0.25 & 0.62 \\
Geomorphology $\times$ location & 1 & 0.19 & 0.19 & 0.03 & 0.86 \\
WIS $\times$ depth $\times$ geomorphology & 1 & 0.96 & 0.96 & 0.17 & 0.68 \\
WIS $\times$ depth $\times$ location & 1 & 5.59 & 5.59 & 1.00 & 0.33 \\
WIS $\times$ geomorphology $\times$ location & 1 & 0.36 & 0.36 & 0.07 & 0.80 \\
Depth $\times$ geomorphology $\times$ location & 1 & 3.47 & 3.47 & 0.62 & 0.44 \\
Residuals & 23 & 128.13 & 5.57 & & \\
\hline
\end{tabular}

interaction among variables. The projection of the linear regression plan of the SWIO species richness as a function of depth and width of the insular shelf on a three-dimensional plot also showed similar slopes in all landscape features (Fig. 3). In this context, it could be argued that the contribution of the landscape features to the SWIO species richness is determined by the depth and width of the island shelf, but also by the age of the lava flow and the distance to the most recent lava flow that were highly correlated with the width of the insular shelf. Therefore, stations characterized by shallow depths, narrow insular shelf, short distance to the most recent lava flow and a relatively young age are colonized by the highest SWIO species richness, whatever their geomorphology or location.

\section{Discussion}

4.1. Influence of selected environmental variables on fish community structure

Width of the insular shelf was the environmental variable with the most influence on the structure of fish communities (Table 2). It was

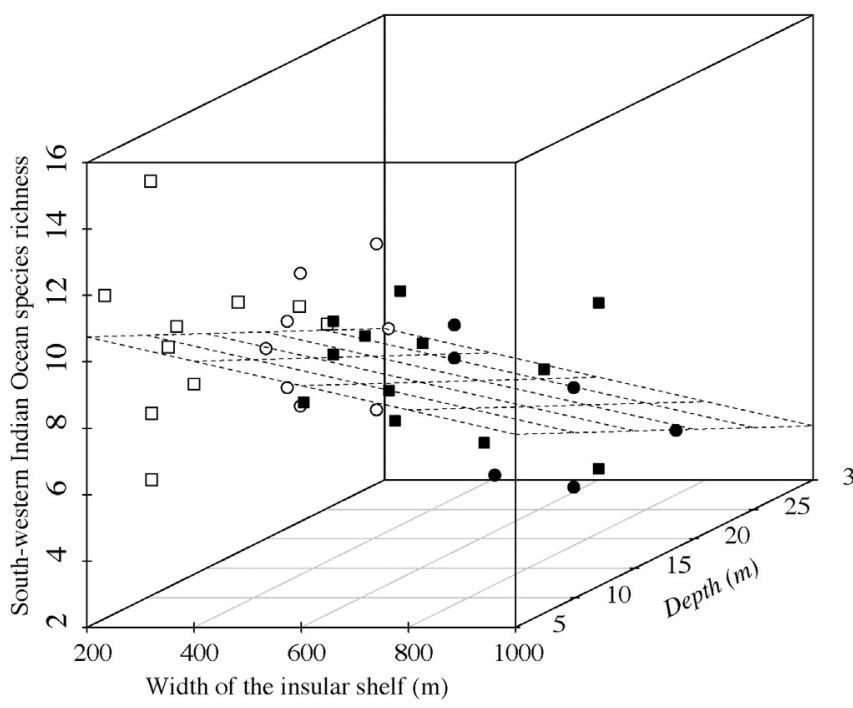

Fig. 3. Three dimension plot of the southwestern Indian Ocean species richness as a function of width of the insular shelf and depth. $\square$, basalt blocks; $\bigcirc$, drop-offs; dark dots, outside volcanic enclosure; clear dots, inside volcanic enclosure. Coefficient of determination of the overall straight-line regression $\left(R^{2}\right)$ on width of the insular shelf $=0.14$ and on depth $=0.24$. strongly correlated with age of the lava flow and distance to the most recent lava flow. This combination of variables had different but related effects on fish assemblages. According to Emslie et al. (2010), the enlargement of the insular shelf may promote more abundant benthic resources and provide more shallow ecological niches. The concept of the niche predicts that more species can coexist in areas with a greater variety of resources, as there would be more potential niches to be occupied by habitat specialists (Hutchinson, 1957). These observations may explain the higher proportions of browsers of sessile invertebrates, feeding on benthic resources, on stations with a larger insular shelf and the greater percentages of diurnal planktivores and omnivores, drawing opportunistically their food from the water column, on stations with narrow insular shelf. Moreover, diurnal planktivores densely colonize environments exposed to tidal currents, along slopes adjacent to deeper water, their main prey (copepods, pelagic tunicates, fish eggs) being more accessible (Friedlander and Parrish, 1998; Hobson, 1991; Hobson and Chess, 1978). It is therefore not surprising to observe them in higher proportions on stations with a narrower insular shelf, characterized by steep slopes within the surveyed area.

Depth was also a very influent variable on the fish community structure. This influence is mainly due to changes in environmental variables such as hydrodynamism, water desalination, light intensity, oxygenation, and exogenous physicochemical inputs and its effects on the availability of food resources, some being more abundant near the surface (algae, corals, phytoplankton) and others at depth (macrobenthic invertebrates, zooplankton). These trends have been studied in many regions and contexts, including Indo-Pacific reefs (Booth and Wellington, 1998; Friedlander and Parrish, 1998), Caribbean reefs (Greenfield and Johnson, 1990; Lara and González, 1998) or rocky Mediterranean shores (Bell, 1983; Dufour et al., 1995). In this study, nocturnal and diurnal planktivores were recorded at greater depths. In addition to the ecological preferences of diurnal planktivores already mentioned, nocturnal planktivores aggregate preferentially in environments protected from wave and current. They are strict carnivores and feed on large organisms (large calanoids, mysids, isopods, amphipods, decapod larvae) (Hobson and Chess, 1978). These environmental conditions are found at greater depths, due to stringent hydrodynamism that was generated by trade wind swells on surface (Letourneur, 1998). Conversely, nocturnal carnivores were recorded in higher proportions in shallow waters. This minority diet (10\% of recorded species) was mainly represented by Cirrhitidae species ( $51 \%$ of nocturnal carnivores occurrences, e.g. C. guichenoti, $C$. mascarenensis, $P$. arcatus), mainly recorded at depths of $20 \mathrm{~m}$ and less (Lieske and Myers, 1994).

It was recognized that rugose substrata may offer more shelter from predators or nesting sites. Gratwicke and Speight (2005) showed that at least $35 \%$ of the fish species observed in a range of shallow tropical marine habitats were positively related to rugosity. Moreover, the high rugosity often offered by coral cover can explain the relationship between rugose substrates and some ecological characteristics such as high percentages in corallivore organisms and high Shannon-evenness indexes (Purkis et al., 2008). These previous results can explain the relationship between rugosity and percentages of browsers of sessile invertebrates, which feed especially on coral polyps but also on other fixed organisms, observed during this study. In a previous work on underwater lava flows of the Piton de la Fournaise, Pinault et al. (2013b) also noted the positive influence of scoriaceous rocks and unconsolidated rubble and boulders of the most recent lava flow on substrate rugosity. This second origin of substrate rugosity could explain the positive relationship between this variable and the percentage of piscivores. Indeed, Godwin and Kosaki (1989) observed on the latest lava flow of the Kilauea volcano, in Hawaii, abundances of juvenile fishes much higher than on other flows. Pinault et al. (in press) also described on the lava flows of the Piton de la Fournaise a mass-settlement event of fish post-larvae spatially restricted to the most recent lava flow. The presence of the recorded piscivorous species feeding mainly on juvenile fish [e.g. Parupeneus cyclostomus (Lacepède, 1801), Pterois antennata (Bloch, 1787), Pterois 
miles (Bennett, 1828), Synodus dermatogenys Fowler, 1912, Synodus variegatus (Lacepède, 1803)] on the most recent lava flows could be related to the abundance of their food resources.

Percentage of soft substrate was the environmental variable demonstrating the least influence on the trophic structure of fish community (Table 2). It seemed, however, to have a significant influence on the occurrence of species (Fig. 2B). Its contribution to the CCA appeared strongly related to characteristic species of the area inside VE, which some feed [e.g. Parupeneus macronemus (Lacepede, 1801)] or shelter (e.g. N. magnifica) by burrowing in the sediment. It is likely that the main influence of this variable on fish assemblages of the study area was not based on food availability, as the close physical link (habitat) between some reef-species and sediment without direct trophic dependence has been described in many studies (e.g. Friedlander and Parrish, 1998; Mellin et al., 2006).

\subsection{Influence of selected environmental variables on species richness}

No significant relation was demonstrated between the non-SWIO species richness and the environmental variables. Conversely, the SWIO species richness showed significant negative relations with width of the insular shelf and depth. Hence the shallower stations with narrower insular shelf, younger age and located closer to the most recent lava flow presented the highest SWIO species richness. In addition, the ANCOVA revealed that, regardless of these environmental variables, the SWIO species richness was not related to geomorphology or location that were the main landscape factors retained within the study area. These results are consistent with Pinault et al. (2013a) that identified the southeast coast of Reunion (active volcanic region) as having the highest percent of the SWIO species of the island with $11.2 \%$ of the total number of species recorded in this region, while the overall fish community of the island contained $8.3 \%$ (Fricke et al., 2009). In comparison, the fish community recorded within study area on stations at depths of $15 \mathrm{~m}$ and less, with an insular shelf narrower than $300 \mathrm{~m}$, which had 7 years old and less and located closer than $8 \mathrm{~km}$ from the most recent lava flow contained 13.2\%.

The 31 endemic species recorded during this survey possess convergent ecological traits. Most were small-bodied ( 25 species, i.e. $81 \%$, had an asymptotic length of $<30 \mathrm{~cm}$ ), encountered in shallow waters ( 25 species, i.e. $81 \%$, were at maximum depth of $<40 \mathrm{~m}$ ), with high fecundity (23 species, i.e. $74 \%$, had a minimum population doubling time of $<15$ months), non-selective diet (10 species, i.e. $32 \%$, were omnivores), and narrow species range-size (22 species, i.e. $71 \%$, were sedentary). The relatively high SWIO species richness observed on the shallower stations with narrower insular shelf, younger age and located closer to the most recent lava flow could be thus the result of these convergent ecological traits, which are characteristic of species commonly found in the early stages of ecological succession (Sandin and Sala, 2012), as this selection of stations was the most intensively affected by volcanic and environmental disturbances of those surveyed. The adaptability of the SWIO species and their strategy of colonization could compensate for their low competitiveness (Odum, 1969; Ramade, 2003).

The SWIO species also seem to depend on specific habitats of the southeastern coast of the island, as this high SWIO species richness has not been recorded elsewhere on Reunion Island (Pinault et al., 2013a). Previous studies have particularly addressed habitats that were exposed to acute and chronic disturbances (estuarine areas, urbanization, bleaching, cyclones) or that were newly submerged (artificial reefs, breakwaters, wrecks, wave power plants). It may be hypothesized that the volcanic influence, that occurred frequently in the SWIO region during the last million years, especially in the Mascarene Islands, may be a factor influencing the apparition of new species adapted to this specific environmental disturbance.

If long distance settlement events seem to be the most frequent speciation mechanism of marine species with the modification of gene flow through time due to changes in biotic and abiotic conditions (Paulay,
2006), other processes like disruptive selection, habitat or resource choice, may occur at smaller geographic scales and lead to sympatric sister-species (Postaire et al., 2014). Moreover, the global cooling that occurred during Oligo-Miocene (23 Ma) caused transient lowerings in sea levels that expanded emerged landmasses and coastlines (Haq et al., 1987). The volcanic activity of the SWIO region started $65 \mathrm{Ma}$ ago and created a north-south oriented chain of islands across the Indian Ocean (Laccadive and Maldivian islands, Chagos archipelago, Mascarene plateau, Mauritius and Reunion islands) (Duncan and Hargraves, 1990; Duncan and Storey, 1992). During low sea-level stands, these islands represented large landmasses. Various taxa used these multiple islands as stepping-stones to colonize the SWIO, while subsequent sea level rises facilitated secondary isolation and speciation (Warren et al., 2010). This mechanism of successive connection and isolation of volcanic island populations, located on a very active geological hotspot, could explain the disruptive selection of species adapted to volcanic habitats and the resulting speciation of sister-species specialized in changing environments and regular food shortages.

\subsection{Fish colonization patterns}

Although no direct relationship has been revealed between underwater landscape factors and fish assemblage variables, each geomorphology and location have been identified by the persistence of environmental variables, which more or less strongly influenced their intrinsic fish community structure (Table 4). This work, conducted to characterize the dependency relationships between fish assemblage and environmental variables, is similar in its interpretation to the Hutchinsonian ecologic niche concept (Hutchinson, 1957), modeling the theoretical area of presence of a species or group of species by the persistence of environmental variables favoring the development of its populations.

In this study, a dual-polarization of the colonization patterns is observed according to the underwater landscape factors, geomorphology and locality, resulting in four distinct ecological features.

Basalt blocks outside VE are identified by the low impact of the most recent lava flows, particularly that of 2007. This relative environmental stability, coupled with shallow depths and a wider insular shelf, allows the development of more structured biological communities characterized by high coral cover and fish assemblages with more specialized diets like browsers of sessile invertebrates. Some characteristic species of this ecological feature, such as $C$. guttatissimus and $P$. arcatus, are considered as exclusively associated with coral reefs (bioconstructed carbonates) (Fricke et al., 2009). Grigg and Maragos (1974) estimated recovery time of areas decimated by recently submerged lava flows in Hawaii to be about 20 to 50 years, depending on the succession stage of the impacted communities. The relative distance from the most recent lava flow of the areas outside VE could thus allow the conservation of structured reef communities, as areas subject to direct volcanic impacts would be characterized by constantly interrupted successions, resulting in pioneer stages.

Drop-offs outside VE are also relatively protected from the influence of the most recent lava flows. However, their location in deeper water attenuates the influence of swell, tidal currents and light energy on biological communities. These conditions limit the development of coral communities, but favor the aggregation of nocturnal planktivores, adapted to low hydrodynamic environments (Hobson and Chess, 1978).

Basalt blocks inside VE are distinguished by their proximity to the most recent lava flows and their regular acute volcanic disturbances. Their shallowness also exposes them to stringent environmental variables such as swell, tidal currents or chronic freshwater inputs. Moreover, the narrowness of the insular shelf, characterized by steep slopes, reduces number of shallow ecological niches and leads to regular food shortages, particularly from benthic resources (Emslie et al., 2010). This very rigorous environment is conducive to colonization by rather broad food spectrum species like omnivores, but also to small nocturnal 
Table 4

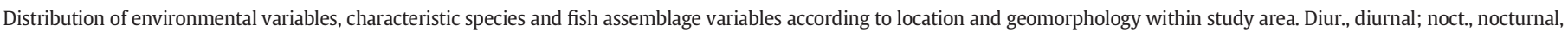
brow. of sess. inver., browsers of sessile invertebrates; perc., percentage; SWIO sp., endemic species from the southwestern Indian Ocean.

\begin{tabular}{|c|c|c|c|c|}
\hline Location & Geomorphology & Environmental variables & Characteristic species & Fish assemblage variables \\
\hline \multirow[t]{2}{*}{ Outside volcanic enclosure } & Multi-metric basalt blocks on compact lava & $\begin{array}{l}\text { Distance to last lava flow } \\
\text { Old lava flows } \\
\text { High coral cover } \\
\text { Width of insular shelf } \\
\text { Shallow-water } \\
\text { Low soft substrate perc. }\end{array}$ & $\begin{array}{l}\text { Aulostomus chinensis } \\
\text { Chaetodon guttatissimus } \\
\text { Gomphosus caeruleus } \\
\text { Hemitaurichthys zoster } \\
\text { Heniochus acuminatus } \\
\text { Myripristis berndti } \\
\text { Naso elegans } \\
\text { Paracirrhites arcatus } \\
\text { Parupeneus trifasciatus } \\
\text { Stegastes pelicieri }\end{array}$ & $\begin{array}{l}\text { Brow. of sess. inver. } \\
\text { Noct. carnivores }\end{array}$ \\
\hline & Drop-offs on sedimentary patches & $\begin{array}{l}\text { Distance to last lava flow } \\
\text { Old lava flows Low coral cover } \\
\text { Width of insular shelf } \\
\text { Deep-water } \\
\text { High soft substrate perc. }\end{array}$ & $\begin{array}{l}\text { Caesio teres } \\
\text { Cephalopholis urodeta } \\
\text { Chromis dimidiata } \\
\text { Ctenochaetus striatus } \\
\text { Forcipiger flavissimus } \\
\text { Labroides dimidiatus } \\
\text { Plagiotremus tapeinosoma } \\
\text { Pomacanthus imperator } \\
\text { Pseudanthias evansi } \\
\text { Pseudocheilinus dispilus } \\
\text { Zebrasoma desjardinii }\end{array}$ & $\begin{array}{l}\text { Brow. of sess. inver. } \\
\text { Noct. planktivores }\end{array}$ \\
\hline \multirow[t]{2}{*}{ Inside volcanic enclosure } & Multi-metric basalt blocks on compact lava & $\begin{array}{l}\text { Nearness to last lava flow } \\
\text { Young lava flows Low coral cover } \\
\text { Narrowness of insular shelf } \\
\text { Shallow-water } \\
\text { Low soft substrate perc. }\end{array}$ & $\begin{array}{l}\text { Acanthurus mata } \\
\text { Bodianus macrourus } \\
\text { Cantherhines pardalis } \\
\text { Chaetodon kleinii } \\
\text { Cirrhitichthys guichenoti } \\
\text { Cirrhitops mascarenensis } \\
\text { Naso unicornis } \\
\text { Parupeneus macronemus } \\
\text { Pomachromis richardsoni }\end{array}$ & $\begin{array}{l}\text { Omnivores } \\
\text { Noct. Carnivores } \\
\text { SWIO sp. richness }\end{array}$ \\
\hline & Drop-offs on sedimentary patches & $\begin{array}{l}\text { Nearness to last lava flow } \\
\text { Young lava flows Low coral cover } \\
\text { Low coral cover } \\
\text { Narrowness of insular shelf } \\
\text { Deep-water } \\
\text { High soft substrate perc. }\end{array}$ & $\begin{array}{l}\text { Acanthurus dussumieri } \\
\text { Chaetodon auriga } \\
\text { Chaetodon madagaskariensis } \\
\text { Chromis chrysura } \\
\text { Coris caudimacula } \\
\text { Ecsenius lineatus } \\
\text { Halichoeres cosmetus } \\
\text { Naso hexacanthus } \\
\text { Nemateleotris magnifica } \\
\text { Pomacentrus caeruleus } \\
\text { Pseudanthias squamipinnis } \\
\text { Zebrasoma gemmatum }\end{array}$ & $\begin{array}{l}\text { Omnivores } \\
\text { Diur. planktivores } \\
\text { Noct. planktivores }\end{array}$ \\
\hline
\end{tabular}

carnivores of the Cirrhitidae family, which find shelter in the numerous topographic irregularities created by scoriaceous rocks and unconsolidated blocks from the most recent lava flows. These conditions are also suitable for colonization by the SWIO species, adapted to changing environments and frequent food shortages, compensating their low competitiveness by their high demographic and environmental flexibility (Odum, 1969; Ramade, 2003).

Finally, drop-offs inside VE are differentiated from basalt blocks by their greater depths, removing them from the direct influence of swell, tidal currents and chronic freshwater inputs, and by their particularly steep geomorphology (vertical cliff on narrow insular shelf). These conditions disfavor the extension of benthic organism cover and constrain fish assemblages to feed opportunistically in the water column (Friedlander and Parrish, 1998; Hobson, 1991; Hobson and Chess, 1978), thus favoring the colonization of these habitats by planktivores.

\subsection{Conclusions}

This study constitutes one of the few works conducted on the colonization of recent lava flows by rocky shore fish communities in coral reef environment. Overall, it addresses the mechanisms of natural selection and speciation of endemics from ecological and behavioral analyzes and not from genetic tools, very frequently used when it comes to evolutionary biology and cryptic species (e.g. Cowman and Bellwood, 2013; DiBattista et al., 2013; Hubert et al., 2012). This empirical approach provides avenues for original interpretation; particularly concerning environmental forces and constraints involved in the selection mechanisms in the SWIO region. It appears that acute pressures of volcanic origin and their direct impact on the abundance and availability of food resources could generate harsh environmental conditions, creating ecological niches weakly coveted by biological communities. This low competition for habitat could then promote the emergence of opportunistic species, especially characterized by a strong demographic and dietary flexibility (Odum, 1969; Ramade, 2003).

\section{Acknowledgments}

We would like to thank the BIOLAVE program team who helped us to conduct the fieldwork in excellent conditions, with a very special thanks to S. Bollard who died accidentally in Madagascar on 13/10/ 2012. We thank anonymous referees for their help in improving the manuscript. The BIOLAVE program was funded by the French Ministry of Higher Education and Research and the French Department of Ecology, Sustainable Development, Transportation and Housing and co-financed by the European Union. The grant for BIOLAVE program was part of the CPER 2007-2013 under the measure GP4 3-01 "protect and enhance the marine and terrestrial biodiversity". [ST] 


\section{References}

Ackerman, J.L., Bellwood, D.R., Brown, J.H., 2004. The contribution of small individuals to density-body size relationships: examination of energetic equivalence in reef fishes. Oecologia 139, 568-571.

Bell, J.D., 1983. Effects of depth and marine reserve fishing restrictions on the structure of a rocky reef fish assemblage in the north-western Mediterranean Sea. J. Appl. Ecol. 20, 357-369.

Bell, J.D., Galzin, R., 1984. Influence of live coral cover on coral-reef fish communities. Mar. Ecol. Prog. Ser. 15, 265-274.

Bellard, C., Leclerc, C., Courchamp, F., 2013. Impact of sea level rise on the 10 insular biodiversity hotspots. Glob. Ecol. Biogeogr. 23, 203-212.

Bertalanffy, L.V., 1938. A quantitative theory of organic growth (inquiries on growth laws II). Hum. Biol. 10, 181-213.

Bollard, S., Pinault, M., Quod, J.P., Boissin, E., Hemery, L., Conand, C., 2013. Biodiversity of echinoderms on underwater lava flows with different ages, from the Piton de La Fournaise (Reunion Island, Indian Ocean). Cah. Biol. Mar. 54, 491-497.

Booth, D.J., Wellington, G., 1998. Settlement preferences in coral-reef fishes: effects on patterns of adult and juvenile distributions, individual fitness and population structure. Aust. J. Ecol. 23, 274-279.

Box, G.E.P., Cox, D.R., 1964. An analysis of transformations. J. R. Stat. Soc. Ser. B 26, $211-252$.

Chabanet, P., Faure, G., 1994. Interrelations entre peuplements benthiques et ichtyologiques en milieu corallien. C. R. Acad. Sci. III 317, 1151-1157.

Chabanet, P., Ralambondrainy, H., Amanieu, M., Faure, G., Galzin, R., 1997. Relationships between coral reef substrata and fish. Coral Reefs 16, 93-102.

Chevallier, L., Vatin-Perignon, N., 1982. Volcano-structural evolution of Piton des Neiges, Reunion Island, Indian Ocean. Bull. Volcanol. 45, 285-298.

Cowman, P.F., Bellwood, D.R., 2013. The historical biogeography of coral reef fishes: global patterns of origination and dispersal. J. Biogeogr. 40, 209-224.

DiBattista, J.D., Berumen, M.L., Gaither, M.R., Rocha, L.A., Eble, J.A., Choat, J.H., Craig, M.T., Skillings, D.J., Bowen, B.W., 2013. After continents divide: comparative phylogeography of reef fishes from the Red Sea and Indian Ocean. J. Biogeogr. 40, 1170-1181.

Dufour, V., Jouvenel, J.Y., Galzin, R., 1995. Study of a Mediterranean reef fish assemblage. Comparisons of population distributions between depths in protected and unprotected areas over one decade. Aquat. Living Resour. 8, 17-25.

Duncan, R.A., Hargraves, R.B., $1990 .{ }^{40} \mathrm{Ar} /{ }^{39} \mathrm{Ar}$ geochronology of basement rocks from the Mascarene Plateau, the Chagos Bank, and the Maldives Ridge. Proc. Ocean Drill. Program Sci. Results 115, 43-52.

Duncan, R.A., Storey, M., 1992. The life cycle of Indian Ocean hotspots. Geophys. Monogr. Ser. 70, 91-103.

Efroymson, M.A., 1960. Multiple regression analysis. In: Ralston, A., Wilf, H.S. (Eds.), Mathematical Methods for Digital Computers. Wiley, New York, pp. 191-203.

Emslie, M.J., Pratchett, M.S., Cheal, A.J., Osborne, K., 2010. Great Barrier Reef butterflyfish community structure: the role of shelf position and benthic community type. Coral Reefs 29, 705-715.

Fowler, A.M., 1987. The development of sampling strategies for population studies of coastal reef fishes. A case study. Coral Reefs 6, 49-58.

Fricke, R., Mulochau, T., Durville, P., Chabanet, P., Tessier, E., Letourneur, Y., 2009. Annotated checklist of the fish species (Pisces) of La Réunion, including a red list of threatened and declining species. Stuttg. Beitr. Naturkunde A 2, 1-168.

Friedlander, A.M., Parrish, J.D., 1998. Habitat characteristics affecting fish assemblages on a Hawaiian coral reef. J. Exp. Mar. Biol. Ecol. 224, 1-30.

Froese, R., Pauly, D., 2012. FishBase. www.fishbase.org (Accessed 13 June 2012).

Godwin, J.R., Kosaki, R.K., 1989. Reef fish assemblages on submerged lava flows of three different ages. Pac. Sci. 43, 289-301.

Gratwicke, B., Speight, M.R., 2005. The relationship between fish species richness, abundance and habitat complexity in a range of shallow tropical marine habitats. J. Fish Biol. 66, 650-667.

Greenacre, M., 2013. The contributions of rare objects in correspondence analysis. Ecology 94, 241-249.

Greenfield, D.W., Johnson, R.K., 1990. Heterogeneity in habitat choice in cardinalfish community structure. Copeia 4, 1107-1114.

Grigg, R.W., Maragos, J.E., 1974. Recolonization of hermatypic corals on submerged lava flows in Hawaii. Ecology 55, 387-395.

Haq, B.U., Hardenbol, J., Vail, P.R., 1987. Chronology of fluctuating sea levels since the Triassic. Science 235, 1156-1167.

Harmelin-Vivien, M.L., Harmelin, J., Chauvet, C., Duval, C., Galzin, R., Lejeune, P., Barnabé, G., Blanc, F., Chevalier, R., Duclerc, J., Lasserre, G., 1985. Visual assessment of fish populations and communities: methods and problems. Rev. Ecol. (Terre Vie) 40, 467-539.

Hiatt, R.W., Strasburg, D.W., 1960. Ecological relationship of the fish fauna on coral reefs of the Marshall Islands. Ecol. Monogr. 30, 65-127.

Hobson, E.S., 1974. Feeding relationships of teleostean fishes on coral reefs in Kona, Hawaii. Fish. Bull. 72, 915-1031.

Hobson, E.S., 1991. Trophic relationships of fishes specialized to feed on zooplankters above coral reefs. In: Sale, P.F. (Ed.), The Ecology of Fishes on Coral Reefs. Academic Press, San Diego, pp. 69-95.

Hobson, E.S., Chess, J.R., 1978. Trophic relationship among fishes and plankton in the lagoon at Enewetak Atoll, Marshall Islands. Fish. Bull. 76, 133-153.

Hubert, N., Meyer, C.P., Bruggemann, J.H., Guérin, F., Komeno, R.J.L., Espiau, B., Causse, R. Williams, J.T., Planes, S., 2012. Cryptic diversity in Indo-Pacific coral-reef fishes revealed by DNA-barcoding provides new support to the centre-of-overlap hypothesis. PLoS One 7, e28987.

Hutchinson, G.E., 1957. Concluding remarks. Cold Spring Harb. Symp. Quant. Biol. 22, 415-427.
Jöreskog, K.G., 1970. A general method for analysis of covariance structures. Biometrika 57, 239-251.

Kaschner, K., Rius-Barile, J., Kesner-Reyes, K., Garilao, C., Kullander, S.O., Rees, T., Froese, R. 2010. AquaMaps: predicted range maps for aquatic species. Version 08/2010. www. aquamaps.org (Accessed 13 June 2012).

Khalaf, M.A., Kochzius, M., 2002. Community structure and biogeography of shore fishes in the Gulf of Aqaba, Red Sea. Helgol. Mar. Res. 55, 252-284.

Labrosse, P., Kulbicki, M., Ferraris, J., 2002. Underwater Visual Fish Census Surveys - Proper Use and Implementation. Secretariat of the Pacific Community Press, Noumea.

Lara, E.N., González, E.A., 1998. The relationship between reef fish community structure and environmental variables in the southern Mexican Caribbean. J. Fish Biol. 53 , 209-221.

Letourneur, Y., 1998. Composition, structures and trophic networks of the fish communities of the windward coast of Réunion Island. Cybium 22, 267-283.

Lieske, E., Myers, R.F., 1994. Collins Pocket Guide to Coral Reef Fishes, Indo-Pacific and Caribbean. HarperCollins, New York.

McCune, B., Grace, J.B., 2002. Analysis of Ecological Communities. MjM Software Design, Gleneden Beach.

McDougall, I., 1971. The geochronology and evolution of the young volcanic island of Reunion, Indian Ocean. Geochim. Cosmochim. Acta 3, 261-270.

McPherson, J.M., Jetz, W., 2007. Effects of species' ecology on the accuracy of distribution models. Ecography 30, 135-151.

Mellin, C., Ferraris, J., Galzin, R., Kulbicki, M., Ponton, D., 2006. Diversity of coral reef fish assemblages: modelling of the species richness spectra from multi-scale environmental variables in the Tuamotu Archipelago (French Polynesia). Ecol. Model. 198, 409-425.

Michon, L., Saint-Ange, F., 2008. Morphology of Piton de la Fournaise basaltic shield volcano (La Reunion Island): characterization and implication in the volcano evolution. J. Geophys. Res. Solid Earth 113, 19-20.

Montgomery, D.C., 1976. Design and Analysis of Experiments. Wiley, New York.

Myers, R.F., 1999. Micronesian Reef Fishes: A Comprehensive Guide to the Coral Reef Fishes of Micronesia, third ed. Coral Graphics, Barrigada.

Odum, E.P., 1969. The strategy of ecosystem development. Science 164, 262-270.

Oksanen, J., Blanchet, F.G., Kindt, R., Legendre, P., Minchin, P.R., O'Hara, R.B., Simpson, G.L., Solymos, P., Stevens, M.H.H., Wagner, H., 2008. Package 'vegan' - community ecology package. R News $8,48-50$.

Paulay, G., 2006. Dispersal and divergence across the greatest ocean region: do larvae matter? Integr. Comp. Biol. 46, 269-281.

Pearson, E.S., 1957. Tests for rank correlation coefficients. I. Biometrika 44, 470-481.

Pinault, M., 2013. Évaluation de la fonctionnalité de récifs artificiels à vocation non extractive, dans un contexte d'habitats naturels fragmentés - Côte nord-ouest de lî̀le de La Réunion. Cybium 37, 262.

Pinault, M., Chabanet, P., Loiseau, N., Durville, P., Galzin, R., Quod, J.P., 2013a. Influence des facteurs environnementaux sur la structure des peuplements ichtyologiques de l'île de La Réunion (Sud-Ouest de l'océan Indien). Cybium 37, 95-109.

Pinault, M., Loiseau, N., Chabanet, P., Durville, P., Magalon, H., Quod, J.P., Galzin, R. 2013b. Marine fish communities in shallow volcanic habitats. J. Fish Biol. 82 $1821-1847$

Pinault, M., Quod, J.P., Galzin, R., 2014. Mass-settlement of the Indian Ocean black-tip grouper Epinephelus oceanicus (Lacepède, 1802) in a shallow volcanic habitat following a tropical storm. Environ. Biol. Fish. http://dx.doi.org/10.1007/s10641-014-03032 (in press).

Postaire, B., Bruggemann, J.H., Magalon, H., Faure, B., 2014. Evolutionary dynamics in the southwest Indian Ocean marine biodiversity hotspot: a perspective from the rocky shore gastropod genus Nerita. PLoS One 9, e95040.

Purkis, S.J., Graham, N.A.J., Riegl, B.M., 2008. Predictability of reef fish diversity and abundance using remote sensing data in Diego Garcia (Chagos Archipelago). Coral Reefs 27, 167-178.

Ramade, F., 2003. Éléments d'écologie: écologie fondamentale, third ed. Dunod, Paris.

Rees, T., 2008. Using AquaMaps for biodiversity assessment, including a prototype MPA (marine protected area) network design tool. In: Weitzman, A., Belbin, L. (Eds.), Biodiversity Information Standards (T. D. W. G.) and the Missouri Botanical Garden. Proc. 2008 T. D. W. G. Annual Conf., Fremantle, pp. 73-74.

Roberts, C.M., McClean, C.J., Veron, J.E.N., Hawkins, J.P., Allen, G.R., McAllister, D.E., Mittermeier, C.G., Schueler, F.W., Spalding, M., Wells, F., Vynne, C., Werner, T.B., 2002. Marine biodiversity hotspots and conservation priorities for tropical reefs. Science $295,1280-1284$.

Sakia, R.M., 1992. The Box-Cox transformation technique: a review. Statistician 41, 169-178.

Sale, P.F., 1991. The Ecology of Fishes on Coral Reefs. Academic Press, San Diego.

Sandin, S.A., Sala, E., 2012. Using successional theory to measure marine ecosystem health. Evol. Ecol. Res. 26, 435-448.

Shapiro, S.S., Wilk, M.B., 1965. An analysis of variance test for normality (complete samples). Biometrika 52, 591-611.

Snedecor, G.W., Cochran, W.G., 1989. Statistical Methods, eighth ed. University Press, Ames.

D.Strasberg, D., 1995. Processus d'invasion par les plantes introduites à La Réunion et dynamique de la végétation sur les coulées volcaniquesEcologie 26, 169-180.

Tanguy, J.C., Bachèlery, P., Le Goff, M., 2011. Archeomagnetism of Piton de la Fournaise: bearing on volcanic activity at La Réunion Island and geomagnetic secular variation in southern Indian Ocean. Earth Planet. Sci. Lett. 303, 361-368.

ter Braak, C.J.F., 1986. Canonical correspondence analysis: a new eigenvector technique for multivariate direct gradient analysis. Ecology 69, 69-77.

Travers, M.J., Potter, I.C., Clarke, K.R., Newman, S.J., Hutchins, J.B., 2010. The inshore fish faunas over soft substrates and reefs on the tropical west coast of Australia differ and change with latitude and bioregion. J. Biogeogr. 37, 148-169. 
Venables, W.N., Ripley, B.D., 2002. Modern Applied Statistics with S. Springer-Verlag, New York.

N.Vigouroux, N., A.E.Williams-Jones, A.E., P.Wallace, P., T.Staudacher, T., 2009. The November 2002 eruption of Piton de la Fournaise, Réunion: tracking the pre-eruptive thermal evolution of magma using melt inclusionsBull. Volcanol. 71, 1077-1089.
Warren, B.H., Strasberg, D., Bruggemann, J.H., Prys-Jones, R.P., Thébaud, C., 2010. Why does the biota of the Madagascar region have such a strong Asiatic flavour? Cladistics 26, 526-538.

Willis, T.J., 2001. Visual census methods underestimate density and diversity of cryptic reef fishes. J. Fish Biol. 59, 1408-1411. 